\title{
DEFINING NEIGHBORS
}


JEWS, CHRISTIANS, AND MUSLIMS

FROM THE ANCIENT TO THE MODERN WORLD

Edited by Michael Cook, William Chester Jordan, and Peter Schäfer

A list of titles in this series appears at the back of the book. 


\section{DEFINING NEIGHBORS}

RELIGION, RACE, AND THE EARLY

ZIONIST-ARAB ENCOUNTER

Jonathan Marc Gribetz

PRINCETON AND OXFORD 
Copyright (C) 2014 by Princeton University Press

Published by Princeton University Press, 41 William Street,

Princeton, New Jersey 08540

In the United Kingdom: Princeton University Press, 6 Oxford Street,

Woodstock, Oxfordshire OX20 1TW

press.princeton.edu

Detail of map: Hans Fischer, Palästina, 1890. Eran Laor

Cartographic Collection, The National Library of Israel.

All Rights Reserved

Library of Congress Cataloging-in-Publication Data

Gribetz, Jonathan Marc, 1980- author.

Defining neighbors : religion, race, and the early Zionist-Arab

encounter / Jonathan Marc Gribetz.

pages $\mathrm{cm}$. - (Jews, Christians, and Muslims from the ancient

to the modern world)

Includes bibliographical references and index.

ISBN 978-0-691-15950-8 (hardcover)

1. Zionism-History-20th century. 2. Palestinian Arabs-History20th century. 3. Jewish-Arab relations. 4. Khalidi, Ruhi, 1864-1913.

5. Ben-Yehuda, Eliezer, 1858-1922. 6. Palestine-History-1799-1917.

7. Palestine-History-1917-1948. I. Title.

DS149.G738 2014

$320.54095694-\mathrm{dc} 23$

2013040012

British Library Cataloging-in-Publication Data is available

This book has been composed in Charis

Printed on acid-free paper. $\infty$

Printed in the United States of America

13579108642 
To Sarit, Sophie, Daniela, and Max 
